\title{
ENHANCEMENT OF CREATIVITY THROUGH LOGO PROGRAMMING
}

\author{
Bens Pardamean and Evelin \\ Computer Science Graduate Program, Bina Nusantara University, Jakarta, Indonesia
}

Received 2013-08-13; Revised 2013-08-20; Accepted 2014-01-23

\begin{abstract}
This study evaluated the effect of Logo programming in enhancing creativity skills. Eighty five fifth-grade students were assigned to experimental and control groups. A pre-test was administered to assess figural creativity factors consisting of receptive fluency, flexibility, originality and elaboration. After eight weeks of Logo programming learning, the experimental group had significantly higher scores compared to the control group on all figural creativity factors. These results revealed significant differences in creativity, especially in flexibility and originality factors. Thus, it is suggestive that Logo programming may provide opportunities for improving student creativity.
\end{abstract}

Keywords: Creativity, Logo Programming, Turtle Geometry

\section{INTRODUCTION}

The rapid development of today's society demands organizations and businesses to be proactive in responding to societal needs. The foresight in capturing these needs is a primary determinant on the impact and status that the newly developed products and services have on society. Education, particularly through schools, is not free from the pressures of business and community development. The use of computer technology in learning and teaching has become increasingly important for educational institutions' efforts in achieving and sustaining an academic competitive edge.

In the past few years, challenging issues in the Indonesian education system have been a major concern for the public. Policy makers have agreed that there is a need for reorganization and revitalization in the education system. Many recommendations had been proposed to remedy the problems. Among them was the suggestion to introduce a method for developing and expanding creative skills in the classroom, on the basis that Information and Computer Technology (ICT) can provide support to this recommendation.
Indonesia's 2004 Curriculum describes the way in which ICT should be used to develop creativity and problem-solving skills, based on a learning model that especially supports subject comprehension (Kurikulum and Depdiknas, 2003). One effort in developing creativity and problem-solving skills is through the utilization of the Logo programming language during the learning process.

Unlike Indonesia, other countries, such as the United States, England, Russia, Australia and Japan, have been using Logo programming for teaching purposes. Logo is widely used in classrooms and is a mandated part of the national curriculum. Research on Logo programming conducted overseas has been done extensively in the past, while its application has been well-established for quite some time, rendering the lack of recent literature on Logo programming.

The purpose of this study was to investigate the effects of Logo programming learning on the creativity skills of young children. This study focused on Logo programming because, as previously described, Logo has great potential for introducing children to many central concepts involved in programming and creativity. Corresponding Author: Bens Pardamean, Computer Science Graduate Program, Bina Nusantara University, Jakarta, Indonesia 


\subsection{Logo Programming}

Logo has been around for quite some time. It was originally developed at the Massachusetts Institute of Technology in 1967 by Papert (1980) with the intention to allow people, even young children, to use computers as a learning tool. Papert is a computer scientist who studies child development for many years. He combined his scientific skills with Piaget's theories on children's learning and thought processes to create a software program that allowed for children to use programming language (Torgerson, 1984).

Maddux and Rhoda (1984) observed that Logo is differ from other programming language in that it can be used even with minute amount of knowledge on computer language. The geometrical component of Logo is known as the turtle geometry. It is the cursor by which the user points and moves within Logo. Only a five or ten-minute presentation is required to introduced the four basic commands for turtle movements. The commands are used to create and manipulate graphics, geometrical shapes and designs, carried out by the turtle, which is a triangular cursor. The turtle's distance and angle are determined by the numerical inputs placed after the direction's commands. In the immediate mode, children instantly learn to create designs, drawings and geometrics figures.

Children type the command and press the ENTER key which moves the turtle. Once the student has mastered the immediate mode, the student can advance to the next level called the program mode. In this level, the commands are no longer carried out individually. A series of commands are written, then the ENTER key is pressed and the command program is executed on the monitor. Thus, Logo provides immediate feedback that allows students to correct and learn from their errors, which then leads to exercising independent self-correction and problemsolving skills.

Logo provides students with a variety of learning strategies. Students with short attention span can benefit from Logo because they can work at their own pace. According to research done by Emihovich and Miller (1988), Logo can also acquire metacognitive skills, which are rarely met in regular classrooms. Planning the turtle's movements provides students with experience based how they think and learn. This higher-level thought process applied to a concrete object teaches them content, thinking process and behavioral strategies needed for academic success.

\subsection{Logo and Creativity}

Silvern (1988) points out that problem-solving strategies and play exercises facilitate creative thinking. Through play exercises, children transform objects into real-world ideas. Constructive play is defined as using ordinary objects and imagination to create a new product. Painting, drawing and building blocks are all forms of constructive play, but a child does not have to think, at least consciously, about creating them. Using Logo, the child must think creatively on a more conscious and involved level because a set of instructions must be followed or produced. Through constucting and transforming original instruction sets, children can develop and express creative thinking.

Clements (1991) corroborates the previous findings when his Logo group significantly outperformed other groups in creativity training studies. Third-grade children were able to create complex projects by combining an entire page of shapes into one drawing. Their drawings were more complete, original and sophisticated compared to that of the control group. According to his study, Clements determines that this is most likely due to their learning of procedural thinking with Logo.

Other studies show an increase in figural creativity on transfer tests, although in some, the gains are moderate (Clements and Gullo, 1984; Reimer, 1985; Horton and Ryba, 1986; Wiburg, 1987; Roblyer et al., 1988; Clements and Nastasi, 1992) and occasionally non-significant (Mitterer and Rose-Drasnor, 1986; Plourde, 1987). However, the originality aspect, in contrast to fluency or flexibility aspect, is most often enhanced.

\subsection{Problem Formulation}

This study was conducted to evaluate whether Logo programming can improve students' creativity amongst fifth-grade students. The main reason this study was conducted on students at this grade level was due to the fact that this age is an ideal time frame for introducing and developing creativity skill.

\subsection{Hypothesis}

This study hypothesizes that Logo programming can enhance student's creativity skill amongst fifthgrade students.

\section{METHODOLOGY}

This study was a quantitative study for learning computer programming in elementary school. It focused on Logo programming subject in a fifth-grade class to 
evaluate its effect on students' creativity skill. The results can be used as a guide to develop creativity skills through the use of ITC for elementary schools.

\subsection{Study Design}

This study was a quasi-experimental quantitative research. Pre-test was given prior to the start of Logo programming course then a post-test was conducted afterward. Thus, the main objective of this study was to assess whether there were changes in the students' creativity skill before and after learning the Logo programming. The conceptual framework for the study is depicted in Fig. 1.

The experimental group studied a module of Logo programming in 16 sessions. One 40-min session course of ICT was a part of their school curriculum. This module ran for a month and produced an introduction of Logo programming through turtle geometry. Students often worked in pairs in order to cover the turtle activities on the computer. Meanwhile, they worked individually for the assessment. The teacher's role was to guide the students and teach the material. A PC Logo for Windows version 6.5b 2002 was utilized in the class. Students in the control group did not receive any special microcomputer experience.

\subsection{Data Collection Method}

Creativity scores were measured by the Creative Thinking Figural Test (CTFT), developed by the University of Indonesia (Munandar et al., 1988). It was originally used by psychologists in Indonesia for their research. This test was given to children from the age of five and up to measure different aspects of ability, such as fluency (FLU), Flexibility (FLX), Originality (ORG) and Elaboration (ELA).

Test of Logo programming skill was measured by using the assessment of Logo programming for Jordanian students. This test was developed by Amal Khasawneh based on his study on the assessment of Logo programming (Khasawneh, 2009).

\subsection{Population}

Subject population of this study consisted of fifthgrade students at a Catholic school near Jakarta, Indonesia. The school is co-education from kindegarden to grade 12 .

The 85 students in the fifth-grade classes were divided into two groups: The Logo experimental group and the control group. The former group consisted of 43 students while the latter 42 students. Each student was assigned to the group based on the intelligence, gender and religion.

\subsection{Sample and Sampling Technique}

A convenience (non-probabilistic) sampling technique was utilized for this study. A probability sample was not necesssary for this research as all the students were participated in the study in some form with a total sample size of 85 students.

\subsection{Analysis Method}

This study evaluated whether the Logo programming learning could improve students' creativity skill amongst fifth-grade students. This study compared the differences of scores in students' creativity before and after the Logo programming course. The pre-test scores were compared to the post-test scores via T-test analysis, matching each student's creativity pre-test and post-test scores.

\section{RESULTS}

During the study, the students' creativity skills preand post-test scores were collected then the scores were classified into two groups, the Logo experimental group and the control group. Independent-samples T-test was performed to test for differences found in the FLU, FLX, ORG and ELA aspects.

Table 1 shows means and standard deviations of the creativity aspects' scores in pre-test for both the experimental and control group participants. In this pretest, the mean scores of FLU did not significantly differ between the Logo experimental and the control groups, F $=0.090, \mathrm{p}=0.818$. The same result also emerged for FLX $(F=2.994, p=0.520)$ and ELA $(F=0.326, p=$ $0.585)$. On the other hand, the mean score of ORG differed significantly $(\mathrm{F}=0.114, \mathrm{p}=0.001)$.

Table 2 presents the means and standard deviations of the creativity aspects' scores in post-test for both the experimental and control group participants. In this posttest, the mean scores of FLU did not differ significantly, $F=0.291, p=0.209$. The same result also emerged for ELA $(F=0.089, p=0.139)$. Meanwhile, the mean scores of FLX was significantly different $(\mathrm{F}=$ $0.387, \mathrm{p}=0.045)$. The same results also emerged for ORG $(\mathrm{F}=0.001, \mathrm{p}=0.033)$.

Figure 2 displays improvements in the students' creativity level between pre-test and post-test scores for the Logo experimental group participants. Each score of the creativity aspect shows consistent improvements in post-test evaluation.

Figure 3 displays relatively modest improvements in student creativity between pre-test and post-test scores for the control group participants. The graph shows incremental scores in all students' creativity scores from the pre-test to the post-test. 


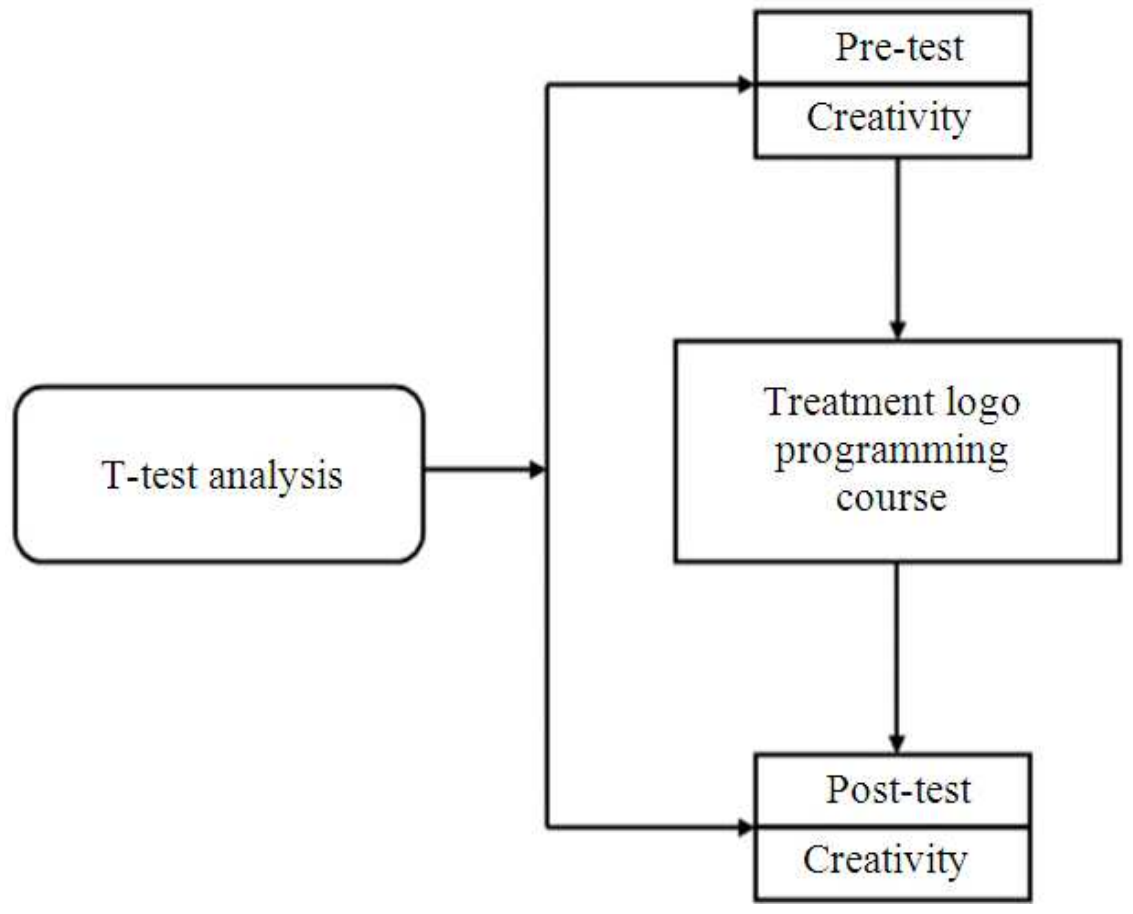

Fig. 1. Conceptual framework for the study

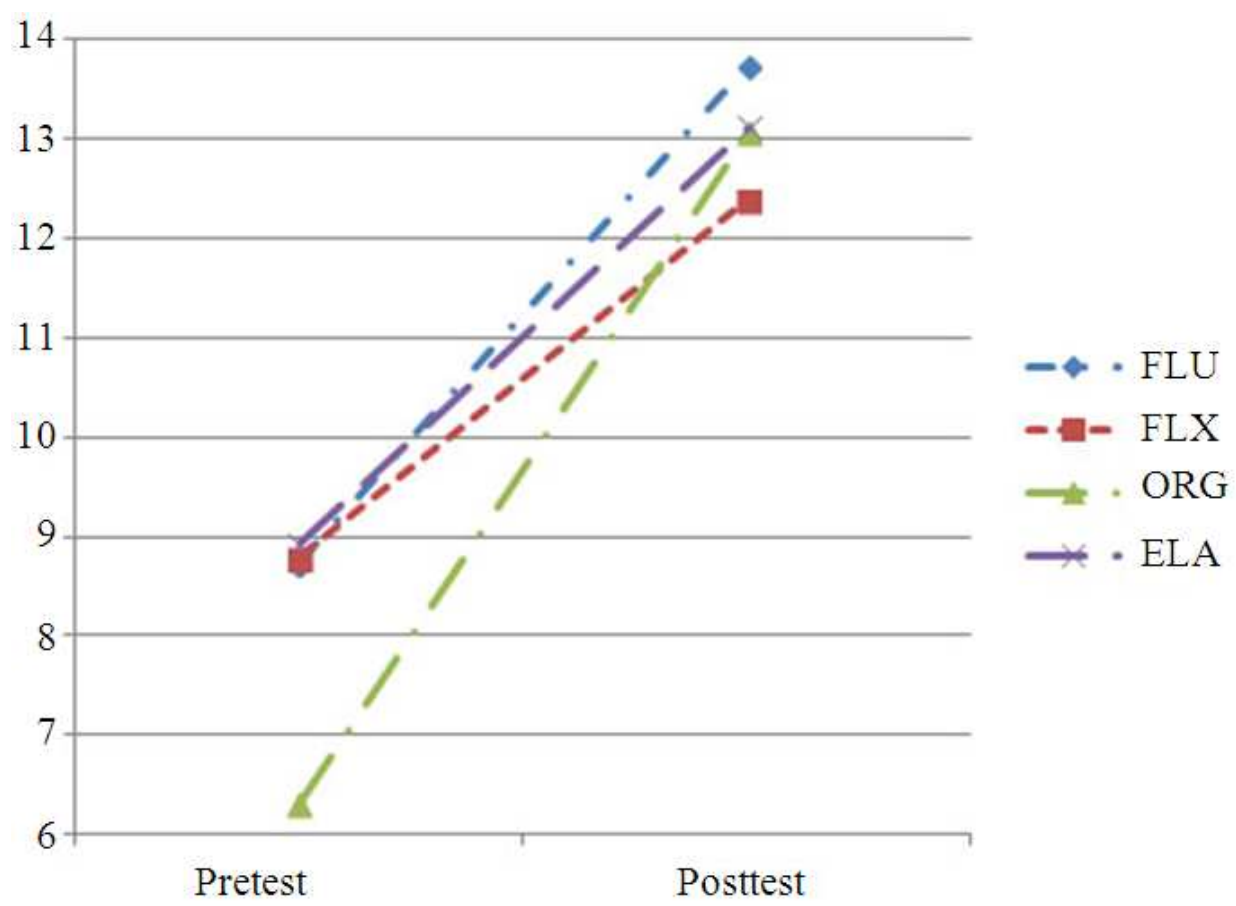

Fig. 2. The creativity pretest-posttest scores for the Logo experimental group 


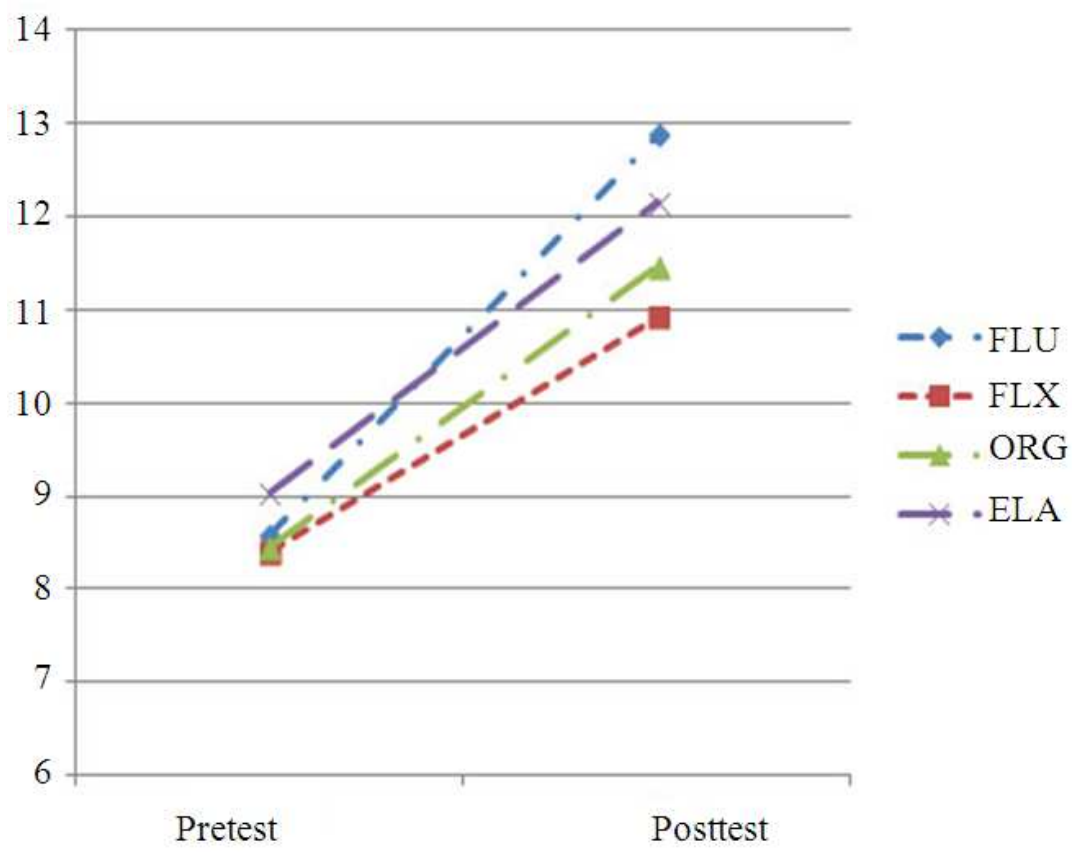

Fig. 3. The creativity pretest-posttest scores for the control group

Table 1. Creativity skills for pre-test score

\begin{tabular}{|c|c|c|c|}
\hline \multirow{2}{*}{$\begin{array}{l}\text { Pre-test } \\
\text { Measured area }\end{array}$} & \multicolumn{2}{|l|}{ Mean (SD) } & \multirow[b]{2}{*}{ p-value } \\
\hline & Experimental group $(\mathrm{N}=42)$ & Control group $(\mathrm{N}=42)$ & \\
\hline FLU & $8.74(2.94)$ & $8.59(2.73)$ & 0.818 \\
\hline FLX & $8.79(2.40)$ & $8.40(2.96)$ & 0.520 \\
\hline ORG & $6.31(2.59)$ & $8.45(2.72)$ & $0.001 *$ \\
\hline ELA & $8.93(3.01)$ & $9.05(3.06)$ & 0.858 \\
\hline
\end{tabular}

* indicates $\mathrm{p}<0.05$

Table 2. Creativity skills for post-test scores

\begin{tabular}{llll}
\hline & Mean $(\mathrm{SD})$ & & \\
Post-Test & $-----------------------43)$ & Control group $(\mathrm{N}=41)$ & p-value \\
Measured area & Experimental group $(\mathrm{N}=43)$ & $0.045^{*}$ \\
FLX & $12.39(3.37)$ & $10.93(3.24)$ & $0.033^{*}$ \\
ORG & $13.07(3.48)$ & $11.46(3.23)$ & 0.139 \\
ELA & $13.12(3.05)$ & $12.15(2.89)$ & \\
\hline
\end{tabular}

$*$ indicates $\mathrm{p}<0.05$

When the experimental and control groups were compared, the amount of improvement in each aspect was more dramatic in the creativity scores from the Logo experimental group participants. Thus, it can be inferred that this occured because of the intervention of Logo programming.

\section{CONCLUSION}

This study concluded that Logo programming learning improved students' creativity skills amongst the fifth-grade students because greater score changes were observed in the Logo experimental group. The 
improvement could be seen through the comparison between the pre- and post-test creativity scores. It showed that there were statistically significant differences in FLX $(\mathrm{F}=0.387, \mathrm{p}=0.045)$ and $\mathrm{ORG}(\mathrm{F}=$ $0.000, p=0.033$ between two groups, indicating that the Logo programming improved the level of students' flexibility and originality aspects of the creativity skills.

\section{RECOMMENDATION}

The lesson on Logo programming language can be incorporated into the curriculum of Indonesian schools in order to develop and expand creativity through the utilization of ICT at the elementary school level; the most optimal result can be best achieved through early administration of the Logo lessons. For future studies, other variables such as gender, socio-economic level, parents' education level, as well as teacher and parental influences, can be included in the analyses.

\section{REFERENCES}

Clements, D.H. and B.K. Nastasi, 1992. Computers and Early Childhood Education. In: Advances in School Psychology: Preschool and Early Childhood Treatment Directions, Gettinger, M., S.N. Elliott and T.R. Kratochwill (Eds.), Lawrence Erlbaum Associates, Hillsdale, NJ., pp: 187-246.

Clements, D.H. and D.F. Gullo, 1984. Effects of computer programming on young children's cognition. J. Educ. Psychol., 76: 1051-1058.

Clements, D.H., 1991. Enhancement of creativity in computer environments. Am. Educ. Res. J., 28: 173-187. DOI: 10.3102/00028312028001173

Emihovich, C. and E.M. Gloria, 1988. Effects of Logo and CAI on black first graders achievement, reflectivity and self-esteem. Elementary School J., 88: 473-487. DOI: $10.1086 / 461551$

Horton, J. and K. Ryba, 1986. Assessing learning with Logo: A pilot study. Comput. Teacher, 14: 24-28.
Khasawneh, A.A., 2009. Assesing logo programming among Jordanian seventh grade students through turtle geometry. Int. J. Math. Educ. Sci. Technol., 40: 619-639. DOI: 10.1080/00207390902912845

Kurikulum, P. and B. Depdiknas, 2003. Kompetensi dasar mata pelajaran teknologi informasi dan komunikasi SD and MI, Jakarta.

Maddux, C.D. and E.C. Rhoda, 1984. Logo is for all children: Learning with the turtle. Except. Parent, 14: $15-18$.

Mitterer, J. and L. Rose-Drasnor, 1986. Logo and the transfer of problem solving: An empirical test. Alberta J. Educ. Res., 32: 176-194.

Munandar, S.C., 1988. Standarisasi tes kreativitas figural. Jurusan Psikologi Pendidikan, Fakultas Psikologi Universitas Indonesia, Jakarta.

Papert, S., 1980. Mindstorms: Children, Computers and Powerful Ideas. 2nd Edn., Basic Books, New York, ISBN-10: 0465046290, pp: 230.

Plourde, R.R., 1987. The insignificance of Logo-Stop "mucking around" with computers. Micro-Scope.

Reimer, G., 1985. Effects of a Logo computer programming experience on readiness for first grade, creativity and self concept: A pilot study in kindergarten. AEDS Monitor, 23: 8-12.

Roblyer, M.D., W.H. Castine and F.J. King, 1988. Assessing the Impact of Computer-Based Instruction: A Review of Recent Research. 1st Edn., CRC Press, ISBN-10: 086656893X, pp: 168.

Silvern, S.B., 1988. Creativity through play with Logo. Childhood Educ., 64: 220-224. DOI: 10.1080/00094056.1988.10521539

Torgerson, S., 1984. Logo in the classroom. Int. Council Compu. Educ., 1-220.

Wiburg, K.M., 1987. The effect of different computerbased learning environments of fourth grade students' cognitive abilities. $\mathrm{PhD}$ Thesis, United States International University. 